\title{
Prescribing Sound: Willem Van de Wall and the Carceral Origins of American Music Therapy
}

\author{
J. Martin Vest
}

From 1921 until 1936, musician Willem Van de Wall pioneered the modern use of therapeutic music in American prisons and psychiatric institutions. His therapy was steeped in the methods and philosophy of social control, and after World War II, it shaped the professionalizing field of music therapy. Van de Wall's influence reveals an overlooked connection between modern clinical practice and the techniques of control employed in prisons and psychiatric hospitals of the early twentieth century. Given music therapy's broader impact as an element of postwar self-help culture, its relationship to social control practices also disrupts longstanding scholarly ideas about the socalled "therapeutic ethos." The therapeutic ethos did not originate solely in efforts by the middle classes to adjust to bourgeois modernity. The case of music therapy suggests that some elements of "therapeutic culture" were always coercive and always directed toward the maintenance of race, gender, and class hierarchies.

A photo taken at New York's Bedford Hills Women's Reformatory in the early 1920s bears testimony to a strange scene (Figure 1). Sunlight pours into a tiled room through two windows, illuminating a group of women sitting in straight-backed wooden chairs. Their hair and clothing convey a sense of orderly uniformity-an impression heightened by the lack of faces: they sit with their backs to us. A single male figure stands before them attending to some kind of wooden cabinet and-if the smudged photographic record of his face is any indication-addresses his audience animatedly. A caption informs that these are members of the Reformatory's contingent of "extra-recalcitrant, psychopaths, and borderline criminal insane" and that "inmates of this type ordinarily need special guards, bolts on doors and bars before windows to prevent assaults, escapes, etc." On this day, however, no such expedients are necessary. The women have gathered to listen to phonographic singing lessons, a ritual that had recently proven as efficacious in controlling their behavior as any drug or physical restraint. ${ }^{1}$

The orchestrator of this strange exercise-and the man in the photograph-was Willem Van de Wall, a Dutch harpist who had performed for years with world-renowned orchestras, first in Europe and then in the United States. Van de Wall had only recently given up this life to pursue another passion: the scientific application of music to social and psychological dysfunctions. This mission took him far from his usual haunts at Carnegie Hall and the New York

\footnotetext{
Many people have given generously of their time to make this a better piece of scholarship. I would like to thank Howard Brick, Molly Brookfield, John Carson, Alexander Clayton, Jay Cook, Henry Cowles, Charles Hiroshi Garrett, David Hutchinson, Perrin Selcer, Deborah Shatin, Judith Shatin, Daniela Sheinin, and David Sheinin. I would also like to thank the staff of the Rockefeller Archive Center, the editors and anonymous readers at Modern American History, and the organizers and attendees of the 2019 Midwest Junto who provided a welcoming environment in which to present early phases of this research.

${ }^{1}$ Willem Van de Wall, The Utilization of Music in Prisons and Mental Hospitals: Its Application in the Treatment and Care of the Morally and Mentally Afflicted (New York, 1924), 28.
}

(C) The Author(s), 2020. Published by Cambridge University Press 


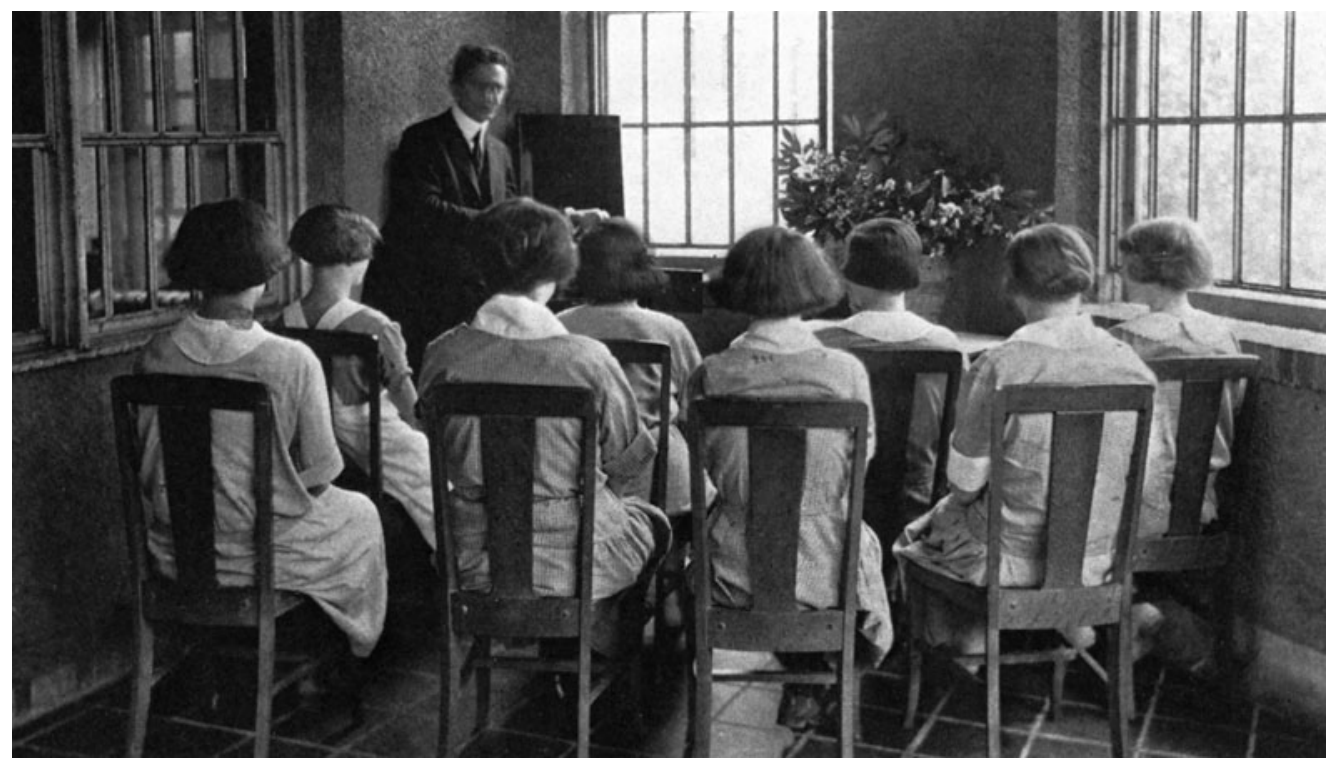

Figure 1. Inmates of the Bedford Hills (NY) Reformatory for Women listen to recorded singing lessons in 1921. The standing male figure is Willem Van de Wall, musician and pioneering music therapist. Published in Willem Van de Wall, The Utilization of Music in Prisons and Mental Hospitals: Its Application in the Treatment and Care of the Morally and Mentally Afflicted (New York, 1924), 28.

Metropolitan Opera House. With the aid of the Russell Sage Foundation and various state agencies in New York and Pennsylvania, Van de Wall spent the years from 1921 to 1936 refining the philosophy and practice of music therapy in the prisons and mental hospitals of his adopted country. By the time he moved on to other professional pursuits (including research in adult education and community music) in the late 1930s, he had penned two seminal monographs as well as a large number of articles on the topic of music therapy.

Van de Wall was not the first to practice or theorize music therapy. African, Asian, and American societies had long employed music for healing. ${ }^{2}$ In the West, stories of music's effects on the mind and body had circulated since antiquity, and books and articles published on music and music therapy often recounted the musico-therapeutic achievements of Pythagoras, the Biblical David, or Thales of Sparta. More recently, musical performances had figured in the routines of American and European psychiatric hospitals, and neurologists and other specialists had begun to investigate the specific physiological effects of music listening on "normal" subjects by the end of the nineteenth century. The use of music in psychiatric institutions, however, had generally been episodic, producing little in the way of practical knowledge. Similarly, laboratory experimentation remained wedded to anthropometric methodologies, which offered very little insight into the possible psychological and sociological effects of music, producing instead reams of data on heart rates and other physiologically reductive measures of music's effects. Despite more than a century of music in modern institutions (and millennia of "common sense" regarding music's curative powers), very little of value could be said about music's effects on the criminal, the mad, or the ill. It was precisely this lacuna that Willem Van de Wall sought to address. Following World War II, a rapidly

\footnotetext{
${ }^{2}$ For medical uses of music across cultures, see Penelope Gouk, ed., Musical Healing in Cultural Contexts (New York, 2016).
} 
growing cohort of full-time music therapists drew on the work of Van de Wall and a handful of other pioneers to forge a new profession with its own values, theories, and practices. ${ }^{3}$

Music therapy has attracted very little scholarly attention, a fact all the more surprising for the topic's relevance to several emerging and dynamic areas of inquiry. ${ }^{4}$ Scholars working in the field of sound studies, for example, have detailed historical and contemporary sonic environments, or "soundscapes," as well as the techniques and technologies used in apprehending and controlling them. ${ }^{5}$ But the field has also charted shifting conceptions and representations of sound, sound's place in the elaboration of social order, and even its centrality to modernity and modern conceptions of the self. ${ }^{6}$ The rise of modern music therapy represents a crucial strand of the larger history of sound's entanglements with self, society, and culture.

Music therapy's history also holds potential insights for historians of the emotions, who, since the early 2000s, have historicized the experience and expression of human emotional states. The emotions, it turns out, have been remarkably contingent and just as subject to the shaping influences of language, practice, and politics as all other aspects of human experience. To date, however, the role of music in shaping, modeling, propagating, and legitimating repertoires of emotionality has received little attention. Indeed, as practiced by Willem Van de Wall, music therapy in the prisons and psychiatric institutions of the United States aimed explicitly at the disciplining of inmates' affective states as well as their outward behaviors. ${ }^{7}$

\footnotetext{
${ }^{3}$ In addition to its historical association with health and healing, music has also been attributed with deleterious effects on human well-being. See Steve Goodman, Sonic Warfare: Sound, Affect, and the Ecology of Fear (Cambridge, MA, 2010); James Kennaway, Bad Vibrations: The History of the Idea of Music as Cause of Disease (Burlington, VT, 2012); and Juliane Brauer, "How Can Music Be Torturous? Music in Nazi Concentration and Extermination Camps," Music and Politics 10, no. 1 (Winter 2016). For early historical surveys of ancient music therapy, see Charles Burney, A General History of Music from the Earliest Ages to the Present Period (London, 1782); George L. Beardsley, "The Medical Uses of Music," The New England Medical Monthly 2, no. 14 (Feb. 1883): 214-6, here 214; and G. Alder Blumer, "Music in Its Relation to the Mind," The American Journal of Insanity 48, no. 3 (Jan. 1892): 350-64, here 362.

${ }^{4} \mathrm{~A}$ handful of articles and book chapters have addressed the early history of American music therapy. These include George N. Heller, "Ideas, Initiatives, and Implementations: Music Therapy in America, 1789-1848," Journal of Music Therapy 24, no. 1 (Mar. 1987): 35-46; William B. Davis, "Music Therapy in 19th Century America," Journal of Music Therapy 24, no. 2 (July 1987): 76-87; Peregrine Horden, "Commentary on Part V with Notes on Nineteenth Century America and on Mesmerism and Theosophy," in Music as Medicine: The History of Music Therapy since Antiquity, ed. Peregrine Horden (New York, 2000), 315-37; William B. Davis, "The First Systematic Experimentation in Music Therapy: The Genius of James Leonard Corning," Journal of Music Therapy 49, no. 1 (Mar. 2012): 102-17.

${ }^{5}$ For briefs on behalf of sonic history, see Sophia Rosenfeld, "On Being Heard: A Case for Paying Attention to the Historical Ear," The American Historical Review 116, no. 2 (Apr. 2011): 316-34; and Richard Cullen Rath, "Hearing American History," The Journal of American History 95, no. 2 (Sep. 2008): 417-31. On soundscapes, see Alain Corbin, Village Bells: Sound and Meaning in the Nineteenth-Century French Countryside (New York, 1998); Richard Cullen Rath, How Early America Sounded (Ithaca, NY, 2003); Emily Ann Thompson, The Soundscape of Modernity: Architectural Acoustics and the Culture of Listening in America, 1900-1933 (Cambridge, MA, 2008); and R. Murray Schafer, "The Soundscape," in The Sound Studies Reader, ed. Jonathan Sterne (New York, 2012), 95-103. On the historical construction and control of sound, see Jonathan Sterne, The Audible Past: Cultural Origins of Sound Reproduction (Durham, NC, 2003); and Karin Bijsterveld, Mechanical Sound: Technology, Culture, and Public Problems of Noise in the Twentieth Century (Cambridge, MA, 2008).

${ }^{6}$ On shifting understandings of noise and sound, see Douglas Khan, Noise, Water, Meat: A History of Sound in the Arts (Cambridge, MA, 1999); Penelope Gouk and Ingrid Sykes, "Hearing Science in Mid-Eighteenth-Century Britain and France," Journal of the History of Medicine and Allied Sciences 66, no. 4 (Oct. 2011): 507-45. On sound and social order, see Jacques Attali, "Noise: The Political Economy of Music," in The Sound Studies Reader, ed. Jonathan Sterne (New York, 2012), 29-39. On sound and modern subjectivity, see Steven Connor, "Sound and the Self," in Hearing History: A Reader, ed. Mark M. Smith (Athens, GA, 2004), 54-66; Veit Erlmann, Reason and Resonance: A History of Modern Aurality (New York, 2010); and Leigh Eric Schmidt, Hearing Things: Religion, Illusion, and the American Enlightenment (Cambridge, MA, 2012).

${ }^{7}$ On uses of music as a form of emotional adjustment, see Tia DeNora, "Music as a Technology of the Self," Poetics 27, no. 1 (Oct. 1999): 31-56; and Alexandra Hui, "Lost: Thomas Edison's Mood Music Found: New
} 
This article examines Willem Van de Wall's career as a crucial moment in the origins of modern music therapy. The music-therapeutic techniques forged by Van de Wall in his work in prisons and psychiatric institutions relied on an explicitly coercive understanding of therapy-one aimed at the control of interned populations. Van de Wall also exercised an outsized (though under-recognized) influence on the field of music therapy in the postwar period. This influence extended through one of Van de Wall's favorite methods of musical social control, a technique called the "ISO Principle" by later music therapists. Though stripped of Van de Wall's language of social control, the ISO Principle has persisted into the twentieth century as a crucial piece of the musico-therapeutic toolkit. In at least one instance it has even escaped into the broader sphere of American life through the culture of self-help.

The following examination of Willem Van de Wall, music therapy, and the ISO Principle represents just one exploration of a broader current within the history of twentieth-century psychiatry and popular culture-one that also saw drama, dance, literature, painting, and drawing utilized for therapeutic ends. If the following analysis is any indication, these arts therapies have been more central to twentieth-century social control than previously imagined. Because of their continuity with quotidian forms of recreation and self-cultivation, arts therapy practices honed within the asylum and the prison have been able to slip their restraints and walk right out the front gate, whistling innocently as they pass cross-armed orderlies and guards. What follows is an analysis of just one such escape narrative. But it is one that gestures toward a larger story of how the logics of institutional control were made "safe" for the broader society.

\section{Willem Van de Wall}

Willem Van de Wall was born in Amsterdam in 1887 and grew to adulthood, as he later characterized it, in "an environment of philosophic culture and refined artistic taste." After studying at the Royal Conservatory of Music in the Hague and then with Leipzig's Gewandhaus Orchestra, he embarked on a career as a professional harpist, playing for several years in orchestras in Russia and Germany. In 1909 Van de Wall married, and the couple immigrated to the United States where the globetrotting musician found work as harpist for the Metropolitan Opera Orchestra the following year. They divorced two years later, and he remarried in 1916. That same year he moved to the New York Symphony, but the arrangement was to be short-lived. War came the following year and Van de Wall answered Uncle Sam's call, enlisting as a harpist in the United States Marine Band in Washington, DC. ${ }^{8}$

Despite his classical training, Van de Wall enjoyed an occasional foray into "lowbrow" culture. He played banjo, memorized advertising jingles, and regularly listened to Jack Benny on the radio. Acquaintances found Van de Wall likable, and it was sometimes suspected that his therapeutic successes owed more to personality than technique. His sense of humor ran toward the self-deprecatory, and he often poked fun at his own imperfect English and his tedious attention to detail. He once wrote to a friend with updates on his plans for a

Ways of Listening," Endeavour 38, no. 2 (June 2014): 139-42. On the historicity of emotions and historical approaches to the same, see William M. Reddy, The Navigation of Feeling: A Framework for the History of Emotions (Cambridge, UK, 2001); Barbara H. Rosenwein, "Worrying about Emotions in History," The American Historical Review 107, no. 3 (June 2002): 821-45; and Nicole Eustace et al., "AHR Conversation: The Historical Study of Emotions," The American Historical Review 117, no. 5 (Dec. 2012): 1487-531. For more recent contributions to the field, see Jonas Liliequist, ed., A History of Emotions, 1200-1800 (London, 2012).

${ }^{8}$ Andrew Krikun, "Community Music During the New Deal: The Contributions of Willem Van de Wall and Max Kaplan,” International Journal of Community Music 3, no. 2 (July 2010): 165-74; Alicia Ann Clair and George N. Heller, "Willem Van De Wall: Organizer and Innovator in Music Education and Music Therapy," Journal of Research in Music Education 37, no. 3 (Oct. 1989): 165-78, here 167; "Music as a Tonic for Diseased Minds," The Baltimore Sun, June 3, 1923, FS7; "How Music Is Saving Thousands from Permanent Mental Breakdown," The Etude, Sept. 1925, 613. 
music therapy program for the United States military, including sections on "Participation by Non-Patient Hospital and Base Personnel and by Visitors" and "The Office of the Coordinator." He introduced the missive, "Dear Samuel ... Some more torture."

Van de Wall likely never received any clinical or scientific training, but he had always harbored an interest in the psychological and sociological effects of music. About the time he joined the United States Marine Band in 1917, he made plans to unite his interests in music and the human mind, self-educating in the fields of "applied psychology, sociology, and aesthetics." The following year he volunteered to serve as a consultant and choral director for the Washington Opera Company-a project of the War Camp Community Service-and during this time he began to develop and apply concrete techniques for the use of music in therapy. His work in Washington attracted the attention of the wider War Camp Community Service network, and by 1920 Van de Wall had taken a position with the organization's New York chapter, practicing his evolving brand of musical therapeutics in New York institutions such as the Boys Club of New York, the New York City Municipal Workhouse, and the Psychiatric Hospital at Islip. ${ }^{10}$

Despite the nearly universal praise heaped on Van de Wall's work in these institutions, he was let go from the Community Service Association in 1921. Fortunately, he had by this time a powerful champion in Dr. Orlando Faulkland Lewis, the secretary of the Prison Association of New York, and a figure well connected to New York City's web of charitable and reform organizations. Lewis had served as Director of Community Singing in the War Camp Community Service, an experience that convinced him of the rehabilitative potential of music and which likely brought him into contact with Van de Wall. Lewis was impressed with Van de Wall's first forays into music therapy, and when he heard of the budding therapist's impending unemployment he quickly formed an organization-the Committee for the Study of Music in Institutions - to help manage and find funding for his work. Most importantly, the committee appointed as its secretary Lee F. Hanmer, director of the Recreation Department of the Russell Sage Foundation. Through Hanmer's intercession, the Russell Sage Foundation soon agreed to contribute $\$ 200$ monthly to Van de Wall's work, a figure supplemented by contributions from private citizens and some of the institutions at which he worked. ${ }^{11}$

Operating under the auspices of the Russell Sage Foundation, Van de Wall continued his work in New York institutions, but it soon became clear that he and the Committee would require additional funding. When the opportunity arose to extend Van de Wall's project to the state of Pennsylvania in 1923, the Committee jumped at the chance, thereby securing additional funding from the Bureau of Mental Health in the Pennsylvania Department of Public Welfare. For the next nine years, Van de Wall split his time between the two states, practicing and refining his approach to music therapy in the hospitals, prisons, and psychiatric institutions of both. ${ }^{12}$

\footnotetext{
9"How Music Is Saving Thousands," 613; Willem Van de Wall to Samuel Hamilton, Jan. 22, 1943, box 13A, folder 119e, subgroup 1, series 3, Early Office Files, Rockefeller Archive Center, Russell Sage Foundation Records, Sleepy Hollow, NY [hereafter RSFR]; Lee F. Hanmer to John M. Glenn, Jan. 17, 1923, RSFR; Willem Van de Wall to Shelby M. Harrison, Nov. 14, 1946, RSFR; Willem Van de Wall to Samuel Hamilton, Feb. 17, 1943, RSFR.

10"Report of Work of Mr. Willem Van de Wall-New York Community Service," Nov. 22, 1921, RSFR; "Statement Concerning Professional Career of Willem Van de Wall," RSFR.

${ }^{11}$ Lee F. Hanmer to John M. Glenn, Nov. 22, 1921, RSFR; E. R. Cass, "A Tribute to Orlando Faulkland Lewis," in The Seventy-Eighth Annual Report of the Prison Association of New York (Albany, NY, 1923), 12-4; Willem Van de Wall, "Music in Correctional Institutions," in The Seventy-Eighth Annual Report of the Prison Association of New York (Albany, NY, 1923), 47-8; Lee F. Hanmer to John M. Glenn, Apr. 4, 1924, RSFR; "Report of Work of Mr. Willem Van de Wall-New York Community Service," Nov. 22, 1921, RSFR; "Financial Statement of January 22, 1923," RSFR.

${ }^{12}$ Lee F. Hanmer to John M. Glenn, Feb. 2, 1923, RSFR; Lee F. Hanmer to John M. Glenn, Apr. 4, 1924, RSFR; "Statement Concerning Professional Career of Willem Van de Wall," RSFR.
} 


\section{Music-Therapeutic Practice}

In the early 1920s Willem Van de Wall entered the chronic ward of an unidentified psychiatric hospital - a place where, he later wrote, one expected to find "very bad men, of whom it is said that they stab one when they get a chance." With an armful of sheet music and a folding organ, he passed through heavily reinforced doors, past steel bars and screens, and then met with his charges, some of whom were in straitjackets. Unshaken, Van de Wall initiated a group singing session, fingering the little folding organ while leading his patients in renditions of folk songs and other familiar pieces. The results were probably mediocre, but he emerged from the session unscathed and returned the next week. And the next. And the next. These men, he discovered in time, were remarkable singers.

The most incorrigible of the patients, a ferocious "South American" who derived pleasure from intimidating others, took particular interest in the exercises, belting the musical selections out in a baritone voice, which he preferred to use "explosively." He promised to behave himself if allowed to attend the sessions every week, and a deal was struck with hospital administration to allow it. Both promises were kept, and before long the patient had been removed from his straitjacket. He participated assiduously. He collected the sheet music at the end of sessions, helped fold Van de Wall's organ, and was even allowed to carry the instrument outside of the ward to Van de Wall's vehicle. When a dramatic revue featuring the hospital's "regular patients" was scheduled, Van de Wall secured a special dispensation for the patient to participate. He attended every rehearsal "on his word of honor" and on the day of the revue he performed marvelously: "With his overflow of energy, which was at the bottom of all his troubles, he sang and acted and danced all the parts, removed the piano and acted as stage-hand." Van de Wall noted that "his bow of recognition to the applause was just a trifle deeper than that of the other players, even as he did everything else in life a little more emphatically than others." A few weeks later, the patient received his discharge and left the hospital. ${ }^{13}$

Van de Wall related the foregoing in his 1924 The Utilization of Music in Prisons and Mental Hospitals, his first extended statement on the subject of music therapy. In the story, we see many of the key elements of his music therapeutic philosophy. The patient's psychosis, Van de Wall informs us, had been a matter of an "overflow of energy" that had been wrongly channeled and which need only be directed toward constructive ends. The patient regained mental health through his own self-discipline-awakened by the enticement of musical expressionand the transformation had manifested in a gradual resumption of rights. From the removal of the straitjacket to occasional forays out-of-doors and attendance at rehearsals in other wards to his eventual discharge, the patient assimilated back into broader society. Finally, the story gestures toward a racialist strain in Van de Wall's thinking. That Van de Wall encountered a patient given to dramatic, "explosive," and violent behavior in a psychiatric hospital is unremarkable. That he should introduce the patient as a "South American," however, suggests

\footnotetext{
${ }^{13}$ Van de Wall, The Utilization of Music, 40-2. The institutions into which Van de Wall carried his vision of therapeutic music were themselves sites of shifting historical theories and practices. By the 1920s, both prisons and psychiatric hospitals had been subjected to over a century of recurring reform movements. For the history of psychiatric institutions, see Roy Porter, Madness: A Brief History (Oxford, UK, 2002); Robert Whitaker, Mad in America (New York, 2001), 3-18; Gerald N. Grob, “The Transformation of American Psychiatry: From Institution to Community, 1800-2000," in History of Psychiatry and Medical Psychology with an Epilogue on Psychiatry and the Mind-Body Relation, eds. Edwin R. Wallace and John Gach (Boston, 2008), 538-41; and Edward Shorter, A History of Psychiatry: From the Era of the Asylum to the Age of Prozac (New York, 1997), 190-238. For the history of prisons, see David J. Rothman, "Perfecting the Prison: United States, 1789-1865," in The Oxford History of the Prison: The Practice of Punishment in Western Society, eds. Norval Morris and David J. Rothman (New York, 1995), 111-29; and Edgardo Rotman, "The Failure of Reform: United States, 1865-1965," in The Oxford History of the Prison: The Practice of Punishment in Western Society, eds. Norval Morris and David J. Rothman (New York, 1995), 169-97.
} 
the stereotype of Latin hot-bloodedness. As it turns out, Van de Wall regularly employed such stereotyped understandings of race and nationality in his work.

In his many statements, speeches, articles, and interviews from 1923 through 1935, Van de Wall described the concrete practices he employed in his sessions, and he crafted a theoretical and philosophical framework to explain and justify them. He also published two full monographs. The first of these, The Utilization of Music in Prisons and Hospitals (1924), detailed Van de Wall's thinking on the mechanics of music, music therapy, and its place in the rehabilitation of prisoners and patients. It offered very little practical advice, however, for the aspiring music therapist. Music in Institutions, published in 1936, on the other hand, provided a detailed roadmap for institutional therapy, with sections devoted to a wide variety of institutional settings, musical activities, and administrative concerns. ${ }^{14}$

Van de Wall argued for a wide range of music-therapeutic activities: listening to recorded music, attending live performances, classroom instruction in music theory and appreciation, impromptu singalongs, and participation in a variety of musical ensembles. In a 1923 report before the Prison Association of New York, Van de Wall described in detail the activities undertaken at the House of the Holy Family, a facility for "delinquent and incorrigible juveniles of the Roman Catholic faith." During his weekly visit on May 24, 1922, Van de Wall began with teachings in music theory and technique. A lesson on the E scale and rhythmic subdivision preceded one on sight reading (with emphasis on the root, third, and fifth of the scale). Van de Wall then led the class through a unit on part singing using the book, "The Little Musical Mouse," and then established a class repertoire in the form of two international folks songs: "Cockles and Mussels" (Irish) and Brahms's "Folk Dance" (Hungarian). The lesson's second unit focused on music appreciation using recorded selections from Robert Schumann's opera Kinderszenen, and Van de Wall concluded with two thematic units combining moral and social lessons with musical selections. The hymn, "Jesus, the Very Thought of Thee," served as entree into a discussion of Christ, while an unidentified song touching on the theme of friendship served as the centerpiece of a conversation on "Personal relations." 15

By the time Van de Wall penned his 1936 Music in Institutions, he had expanded his arsenal of music therapeutic techniques to encompass a wide variety of exercises, including instrumental performance. For intellectually disabled individuals in institutions for the "mentally deficient," he prescribed instrumental music in the form of the rhythm orchestra-an ensemble made up of cymbals, triangles, tambourines, drums, and other non-pitched instruments. For those deemed slightly more educable, there were harmonica bands and drum-and-bugle corps, and for those still more advanced, the band, with its complement of brass, woodwind, and percussion instruments. He warned, however, that "the refined feeling, intellectual discrimination, and artistic initiative of the mature musician will not, as a rule, be found even in the higher grades of mentally deficient instrumentalists." For that reason, stringed orchestral instruments such as violins and cellos (which require a high degree of musical mastery) should not be introduced in institutions for the so-called "feeble-minded." In psychiatric hospitals, Van de Wall believed, the music therapist might introduce the full range of instrumental music, from rhythm ensembles to orchestras. Especially in band and orchestra work, one could expect mixed results, as few patients in these institutions had any prior training in instrumental music, while "to acquire and maintain a technique requires more mental energy than most patients in their states of illness can summon." Correctional institutions presented the most promising field for instrumental work because their occupants were often interned for many years. Consequently they were able to invest the large amount of time necessary to master a musical

\footnotetext{
${ }^{14}$ Van de Wall, The Utilization of Music; Willem Van de Wall and Clara Maria Liepmann, Music in Institutions (New York, 1936).

${ }^{15}$ Van de Wall, "Music in Correctional Institutions," 56.
} 
instrument and to play it in an ensemble. It was not unusual for a prison band or orchestra to be the best in the community. ${ }^{16}$

For Van de Wall, however, the most flexible and widely applicable music-therapeutic approach remained singing, and he classified vocal activities according to two broad designations: "that done spontaneously without musical and vocal training, and that done for artistic purposes by means of an acquired vocal technique." The first, he believed, was most applicable to work in institutions and took the form of community singing- "gatherings of the inmate population where most of those present take part in the singing." These meetings, he argued, should last no longer than thirty or forty-five minutes and in some institutions might occur as often as once a week. In many cases, however, once or twice a month sufficed. ${ }^{17}$

In his emphasis on singing, Van de Wall drew on cultural currents well established in American and trans-Atlantic contexts. Group singing had, of course, played a crucial role in the rhythms of religious and educational life in the United States since the colonial period, but in the nineteenth century, amateur group singing had become more widespread and better organized. Beginning in the 1840s, amateur all-male singing groups modeled on the German männerchor proliferated across the United States wherever German immigrants settled in large numbers. By the end of the century, this tradition of group singing had spawned the American glee club movement, with singing ensembles founded on most college campuses in the United States. ${ }^{18}$ More recently, the cause of group singing had been taken up by civicminded music teachers and others. Beginning in 1913, participants in the "community song" movement sought to cultivate a more musical civic culture in the United States through the publication of standardized songbooks and the encouragement of singing in schools and communities. During World War I, they established "Liberty Choruses" to bolster wartime morale in communities. Group singing, then, was a recognized and accepted aspect of American social life that recommended itself readily to application to the problems of institutional populations. $^{19}$

\section{Van de Wall's Theory of Music Therapy}

As a music therapeutic pioneer, Van de Wall could draw on no pre-existing body of theory to guide, explain, and rationalize his work with patients. Consequently, he evolved his own-quite sophisticated-theoretical apparatus that drew together various intellectual currents. Above all, he maintained a faith in the potential remediation of mental illness and criminality, and in this he was influenced by the emergent mental hygiene movement as well as the New Criminology. Together, these currents made it possible to conceive of mental illness and criminality as on the same plane of socio-psychological dysfunction and to prescribe similar measures for the treatment of each.

Beginning in the years just prior to the Great War, the mental hygiene movement focused on mental health in the general population, emphasizing preventative treatment as well as the existence of more quotidian psychiatric and social dysfunctions than those treated in psychiatric hospitals. While the central thrust of the mental hygiene movement was out of the hospitals

\footnotetext{
${ }^{16}$ Van de Wall and Liepmann, Music in Institutions, 121-65, here 136, 150.

${ }^{17}$ Ibid., 196, 198-200.

${ }^{18}$ Jeremy D. Jones, "Male Choirs: A Brief Historical Overview of the European Tradition of Male Singing Societies and Their Influence on the Development of Collegiate Glee Clubs in America: Part I," Choral Journal 48, no. 10 (Apr. 2008): 41-8. For singing societies in nineteenth-century Germany, see Myles W. Jackson, Harmonious Triads: Physicists, Musicians, and Instrument Makers in Nineteenth-Century Germany (Cambridge, MA, 2006), 45-74. For more on the role of singing in American colleges, see J. Lloyd Winstead, When Colleges Sang: The Story of Singing in American College Life (Tuscaloosa, AL, 2013).

${ }^{19}$ Patricia S. Foy, "A Brief Look at the Community Song Movement," Music Educators Journal 76, no. 5 (Jan. 1990): 26-7.
} 
into society-at-large, the medicalization of everyday life implied that just as no one was fully sane, no one was fully insane. A great many psychiatric patients, experts believed, could be reached and brought back to mental health through the same methods used by the "normal" to restore confidence or soothe jangled nerves. ${ }^{20}$

The mental hygiene movement's environmentalism owed much to psychoanalysis, enthusiasm for which had been stoked by Sigmund Freud's lectures at Clark University in 1909. The Freudian framework emphasized environment, especially childhood relationships and experiences. It de-emphasized heredity and earlier psychiatric frameworks' preoccupation with degeneration, and placed at the center of its understanding of mental illness the operations of the unconscious. Its psychological (rather than physiological) orientation stood in stark contrast to the somaticism prevalent in early twentieth-century institutional psychiatry. In the United States, psychoanalysis tended to lose much of Freud's fatalism-especially his emphasis on the irreconcilable nature of psychological conflict. Instead, American mental hygienists found in Freud's environmentalism a justification for belief in human malleability and the possibility of successful remediation. ${ }^{21}$

In addition to psychoanalysis, the mental hygiene movement also drew from the work of one of its early champions, Adolf Meyer. Like psychoanalysis, Meyer's "psychobiology" attributed at least some mental illness to the potentially correctable operations of the mind itself, rather than to incurable lesions or degeneration of the brain. Meyer, however, differed from Freud in his emphasis on evolutionary adaptation. Following American Pragmatists like William James, Meyer argued that the mind was not simply an evolutionary fluke, but rather a crucial element of humanity's adaptation to its environment. ${ }^{22}$

Van de Wall cited mental hygienists liberally in his publications, but his optimistic environmentalism also drew on currents within contemporary penology and criminology, fields shaped by some of the same intellectual influences as the mental hygiene movement. The New Criminology rejected timeworn understandings of criminality and delinquency as a matter for moralistic finger-wagging and attributed them instead to bad upbringing and psychological maladjustment. ${ }^{23}$ Not punishment, but therapy was the appropriate response to these social ills, and to this doctrine Van de Wall gave unequivocal assent. Traditional penal philosophy, he wrote in 1924, represented a policy of "social retaliation" that did little more than convert the unfortunate victim of circumstances into a committed criminal at great public cost. Far better to rehabilitate through music therapy and other measures those inmates who could be salvaged. $^{24}$

While Van de Wall joined with a wide variety of mental health practitioners and other intellectuals in his ideas about the remediable nature of criminality and mental illness, his prescription-music therapy-was more idiosyncratic. Even here, though, he could and did draw on contemporary intellectual currents to make sense of his preferred therapeutic regimen. His understanding of the psychiatric efficacy of music rested on two theoretical components. First, he argued, certain "vitalist forces" governed the human psyche, and these forces "contend[ed] for mastery among themselves, either to the benefit or the detriment of the health of the human being." Here, Van de Wall drew on the vitalist tradition in the philosophy of the life sciences, a current of thought with origins in the late Enlightenment's backlash against radical mechanism. According to vitalists, living things could not be explained through strictly mechanical conceptions of causality, but rather, mysterious, internal, and purposive forces

\footnotetext{
${ }^{20}$ Gerald N. Grob, Mental Illness and American Society, 1875-1940 (Princeton, NJ, 1983), 144-78.

${ }^{21}$ Nathan G. Hale, The Rise and Crisis of Psychoanalysis in the United States: Freud and the Americans, 19171985 (New York, 1995), 3-9, 74-101.

${ }^{22}$ S. D. Lamb, Pathologist of the Mind: Adolf Meyer and the Origins of American Psychiatry (Baltimore, 2018).

${ }^{23}$ See the bibliography in Van de Wall and Liepmann, Music in Institutions, 419-20. See also Hale, The Rise and Crisis of Psychoanalysis in the United States, 91-3.

${ }^{24}$ Van de Wall, The Utilization of Music, 13-7.
} 
guided biological processes toward the growth and maintenance of the organism. ${ }^{25}$ Because turn-of-the-century psychologists harbored doubts about thoroughgoing mechanical reductivism, psychologists were sometimes sympathetic to vitalism with its voluntaristic implications. $^{26}$ Those so inclined could draw on a vitalist tradition in psychological thought (particularly rich in France) going back to the eighteenth century. ${ }^{27}$

Vitalism's compatibility with ideas of will would have appealed to Van de Wall's own preoccupation with the regulation of the self, and here enters the second of Van de Wall's theoretical foundations-self-discipline. The job of maintaining balance of one's vital forces, he argued, belonged to the individual. "Many cases of delinquency and mental sickness," he told the Baltimore Sun in 1923, "are caused by what we would call a maladjustment of the various human energies ..." and that in these cases "a general beneficent controlling will-power was often partly lacking or totally undeveloped...." Since at least the time of Saint Augustine, "will" had denoted a unitary executive agency belonging to the individual that allowed her to control her passions and impulses. In subscribing to such a notion, however, Van de Wall parted ways with a great many contemporary psychologists who, since the turn of the century, had preferred talk of "drives" or "instincts" to that of willpower. In his emphasis on will, Van de Wall likely drew on more popular treatments of the concept, inspired in part by a veritable craze for the ideas of German philosopher Friedrich Nietzsche in the early 1900s. In the United States and England, books were published well into the twentieth century with titles such as The Education of the Will: The Theory and Practice of Self-Culture and Power of Will: A Practical Companion Book for Unfoldment of the Powers of the Mind. ${ }^{28}$

The healing power of song, Van de Wall believed, obtained in its capacity to help re-route the patient's vital energies. By strengthening the executive function-the "will power"-on which depended the patient's capacity for self-discipline, music helped him channel his vital energies away from an unbalanced and destructive state and toward a balanced and constructive one. "Music," Van de Wall informed the 1922 Congress of the American Prison Association,

... is a sensory stimulant to which most of the human and some of the animal species react by releasing at once various forms of latent physical and mental energy, in internal and external activity, or by intensifying some of the forces which are already functioning. Gland secretions, muscular impulses, nerve currents, waves of circulative energy-all feed the machinery contributing to that mystery, consciousness-creation contemplating itself. $^{29}$

\footnotetext{
${ }^{25}$ Peter Hanns Reill, Vitalizing Nature in the Enlightenment (Berkeley, CA, 2005), 5-9; Elizabeth A. Williams, A Cultural History of Medical Vitalism in Enlightenment Montpellier (New York, 2003), 3-5.

${ }^{26}$ On the teleological tendencies of psychological thought in the late nineteenth and early twentieth centuries, see John D. Greenwood, "Mechanism, Purpose and Progress: Darwin and Early American Psychology," History of the Human Sciences 21, no. 1 (Feb. 2008): 103-26.

${ }^{27}$ On vitalism in French psychology, see Alisa Schulweis Reich, "Paul Joseph Barthez and the Impact of Vitalism on Medicine and Psychology" (Ph.D. diss., University of California, Los Angeles, 1995). The writings of Henri Bergson also spurred interest in vitalism in the early twentieth century. See Frederick Burwick and Paul Douglass, The Crisis in Modernism: Bergson and the Vitalist Controversy (Cambridge, UK, 1992).

${ }^{28}$ Willem Van de Wall, "Music as a Means of Mental Discipline," Archives of Occupational Therapy 2, no. 1 (Feb. 1923): 1-26, here 2; "Music as a Tonic for Diseased Minds," FS7; Jules Payot, The Education of the Will: The Theory and Practice of Self-Culture, trans. Smith Ely Jelliffe (New York, 1914); Frank C. Haddock, Power of Will: A Practical Companion Book for Unfoldment of the Powers of Mind (Meriden, CT, 1916). On the history of concepts of the will, see G. E. Berrios and M. Gili, "Will and Its Disorders: A Conceptual History," History of Psychiatry 6, no. 21 (1995): 87-104. On Nietzsche's reception in the United States, see Jennifer Ratner-Rosenhagen, American Nietzsche: A History of an Icon and His Ideas (Chicago, 2012).

${ }^{29}$ Willem Van de Wall, "Music as a Means of Discipline," in Proceedings of the Annual Congress of the American Prison Association, Detroit, Michigan, October 12th to 18th, 1922 (New York, 1922), 150-60, here 151.
} 
Music, in Van de Wall's understanding, stimulated the human organism at the most basic animal level and sparked the individual will. This increase in vital energy spilled over into other channels providing the patient with the psychic energy necessary to put his mental affairs in order. The idea owed much to the Freudian concept of "sublimation," especially as taken up by progressive educational reformers. In short, sublimation posited a re-routing of instinctual drives (especially those of sex and violence) into more "civilized" pursuits. In 1923 Van de Wall explained that music therapy created in subjects a "whole system of beautiful, good, healthy and moral sentiments and thoughts in the realm of the psychical sublimation of the sex-instinct, a complex with strong potentialities for resisting and suppressing the atavistic beast within us...."30

For Van de Wall, however, psychological explanations of mental illness and criminality remained insufficient. In the Netherlands of his early adulthood, the mental hygiene movement had taken on a particularly sociological caste, and this orientation is evident in Van de Wall's own pronouncements on mental health. ${ }^{31}$ In his understanding, mental illness was itself generally characterized by a form of "extreme individualism," requiring the patient to be re-adjusted to his social environment. In mental hospitals and prisons, he argued, one found large numbers of inmates suffering from some form or another of such egocentrism. Those of the "projective" variety, of course, engaged in conspicuously antisocial behavior, loosing their uncontrolled egoistic impulses on others. But other "extreme individualists" were introverts who closed themselves off from the group. Especially in serious cases of mental illness, the introverted extreme individualist "may live in a dream world and react to reality as if it were the world of which he dreams." Van de Wall argued that "this egocentricity, or subjectivity, makes it hard even for an adult to develop attitudes based on objective interests, which is necessary for his social integration." Every session of music therapy, he told the Baltimore Sun in May 1923, helped the institutional inmate "lose a little bit of his morbid individualism."32

Mental health, in Van de Wall's reckoning, ultimately obtained in "adjustment" to one's social environment - a sentiment owing much to Adolf Meyer's adaptive understanding of the mind. At the most superficial level, this "adjustment" entailed a tamping down of behaviors obnoxious to one's immediate neighbors. In one 1923 publication, Van de Wall enjoins readers to imagine a little boy "whose harsh, domineering voice is always heard telling wondrous things about his extraordinary self." But this particular little boy finds himself in one of Van de Wall's music therapy sessions. The music begins, and behold, his "self-worship" becomes inaudible amid his peers' singing. Further, he has no choice but to join in: "If he stands out by doing any kind of thing outside of that which is expected from everybody at the same moment in the same way in the musical exercise, he eliminates himself from that which he inwardly likes so very much...." He must participate or risk social marginalization. But Van de Wall aimed at a more substantial reconfiguration of self than mere "good behavior," and he occasionally hinted at a deeper social metaphysics of "harmony." In 1927, for example, he told the New York Times that "beautiful sounds in some mysterious way act as a general harmonizer of the ego; leading the individual, consciously or unconsciously, to conform in thought and action to the fundamental law of order in the scheme of things." Elsewhere he relied on

\footnotetext{
${ }^{30}$ Van de Wall, "Music in Correctional Institutions," 61. Hale, The Rise and Crisis of Psychoanalysis in the United States, 90 .

${ }^{31}$ After 1900, Dutch mental health practitioners such as F. J. Soesman (to whom Van de Wall attributed a personal influence) argued for a close relationship between social problems and mental illness as well as society's moral duty to ameliorate both. Harry Oosterhuis, "Mental Health as Civic Virtue: Psychological Definitions of Citizenship in the Netherlands, 1900-1985," in Engineering Society: The Role of the Human and Social Sciences in Modern Societies, 1880-1980, eds. Kerstin Brückweh, Dirk Schumann, Richard F. Wetzell, and Benjamin Ziemann (New York, 2012), 159-78. On Van de Wall's debt to Soesman, see Van de Wall, "Mental Discipline," 1.

${ }^{32}$ Van de Wall and Liepmann, Music in Institutions, 34-5, 42; "Music Therapy to Be Used as Insanity Cure," Baltimore Sun, May 30, 1923, 22.
} 
more explicitly collectivist formulations to express the aim of his music therapy. Through music, he wrote, one "becomes a vital part of that wonderful organism the group, in which the individual can reach out to an artistic and energetic height which he can never reach alone." 33

Van de Wall's preoccupations with the self-disciplining of "vital forces" and with social adjustment explained-and justified-some of his beliefs about music itself. He harbored a suspicion, for example, of the phonograph, and was particularly wary of its deployment in mental hospitals. Because he perceived it as potentially (though not necessarily) passive, the consumption of recorded music always threatened to lead patients into pathological subjectivity, withdrawal, and egocentrism. Participatory music, on the other hand, required that the patient's mental energy be channeled outward into objective reality and that his behavior be "adjusted" to those of his fellows. ${ }^{34}$

Van de Wall's understanding of "adjustment," on the other hand, imparted a relativistic strain to his choice of musical selections. Essential to music's medical value were patients' personal and collective associations to the selections sung or played. Artistic considerations came a distant second in this calculus and for that reason, he believed, popular tunes, folk songs, and other well established and familiar pieces were generally more efficacious in therapy than art music. ${ }^{35} \mathrm{He}$ valued folks songs in particular because they expressed "emphatically and loudly as possible [humanity's] emotional reactions on the moral adjustments of individuals and of groups." ${ }^{36}$ At the same time, his interest in music's role in moral instruction initially spurred him to reject jazz. In one of his earliest public statements to the press, Van de Wall fulminated against the new sound, calling it "the greatest advertisement for haunts of vice and sin." By the end of that year, however, he had evolved a more ambivalent stance on jazz, believing that it could "soothe and transform the lower emotional trends into currents of loftier endeavor and expression." Again, Van de Wall's debt to psychoanalytic sublimation is clear. ${ }^{37}$

Van de Wall framed his expansive attitude toward repertoire as a concession to therapeutic criteria, but his ecumenism also drew on a recently expanded set of artistic standards. The nineteenth century had seen the crystallization of a hierarchical conception of culture in the United States, with stark distinctions made between "highbrow" and "lowbrow" entertainments. ${ }^{38}$ By the early twentieth century, however, the hierarchical model of culture had come under withering fire from several directions. The disciplines of folklore studies and anthropology, though rooted in civilizationist and even imperialist projects, had cleared room for a more clearly relativistic understanding of human difference by 1900. In this newer formulation, "culture" served less as a normative designation for "high" artistic achievement and more as a particular human grouping's unique complement of ideas and practices. ${ }^{39}$ Within the ambit of "legitimate" music, nineteenth-century nationalism and the search for national musics had similarly encouraged composers and concertgoers to accept and even prize the particular, the idiosyncratic, and the exotic in ways that sat in tension with high art's pretense to universality. In the United States, the Czech composer and director of the National Conservatory of Music

\footnotetext{
${ }^{33}$ Willem Van de Wall, Music's Mission in Correctional Personality Reconstruction (Albany, NY, 1923), 211; "Music Exercises Curative Powers," New York Times, Jan. 9, 1927, 12.

${ }^{34}$ Van de Wall and Liepmann, Music in Institutions, 138-9.

35"Music Therapy to Be Used as Insanity Cure," 22.

${ }^{36}$ Van de Wall, "Music as a Means of Discipline," 158.

37 "Labels Jazz New Sensual Anthem," Detroit Free Press, May 28, 1922, 9; Van de Wall, "Music as a Means of Discipline," 152. On early responses to jazz in the United States, see James Lincoln Collier, The Reception of Jazz in America: A New View (New York, 1988); and Maureen Anderson, "The White Reception of Jazz in America," African American Review 38, no. 1 (Spring 2004): 135-45.

${ }^{38}$ On cultural hierarchy in the United States, see Lawrence W. Levine, Highbrow, Lowbrow: The Emergence of Cultural Hierarchy in America (Cambridge, MA, 2002).

${ }^{39}$ Karl Hagstrom Miller, Segregating Sound: Inventing Folk and Pop Music in the Age of Jim Crow (Durham, NC, 2010).
} 
of America, Antonín Dvořák, famously drew on African American and Native American musical precedents in composing his 1893 New World Symphony. ${ }^{40}$ In the twentieth century, modernist composers like Richard Strauss, Gustav Mahler, and Igor Stravinsky challenged the distinction between music and noise with an expanded pallet of rhythms and harmonies that critics often denounced. Only in this environment of quickly expanding definitions of artistic and musical legitimacy could Van de Wall (and his funders) conceive of folk and popular music as therapeutic. ${ }^{41}$

Van de Wall's broadminded approach toward repertoire, however, was not without its limits. As Susan Hegeman has argued, hierarchical understandings of culture persisted into the twentieth century, melding with the new relativistic strain of thinking to forge a new "middle brow" culture. While recognizing the plural nature of "culture," Van de Wall and many others of his generation still reserved a central role in their thinking for civilizational ideology and racial stereotype. $^{42}$ In his early, pricklier, phase, for example, Van de Wall had expressed a belief that "jazz originated among the lowest forms of civilization." And in a 1922 address before the Prison Association of New York, Van de Wall recounted his activities at New York City's Women's Workhouse. At points, the narrative devolves into a catalogue of musicodemographic stereotypes. "Eli, Eli," a "classic Jewish dramatic religious anthem," was rendered with "despair and religious ecstasy" by one Polish immigrant. A French girl sang "La Reve de Manon," effecting "the angelic sonority of the French light soprano" followed by "a Spanish girl whose morality was as slender as her figure, but who was sublime in her rhythm ..." and who sang "La Paloma." 43 These stereotypes were not incidental to Van de Wall's understanding of the music therapeutic process. Because the selection must reach the patient at his own level, it was important to account for "racial" predispositions. In his 1924 The Utilization of Music in Prisons and Mental Hospitals, he related how he had helped rehabilitate one mental patient-a dementia praecox paranoid case-with a recording of "O Sole Mio" by famous Italian tenor Enrico Caruso. "Was the patient himself Italian?" Van de Wall imagines his reader asking. "Surely," he answers, "otherwise the Caruso record would not have been selected." The logic of the choice was straightforward: "... to arouse certain racial emotional responses one must give racial emotional stimuli. And Caruso cannot be surpassed-as far as Italians are concerned." 44

Van de Wall vacillated on his understanding of these racial influences. Sometimes he portrayed them as cultural or environmental factors, as in his thoughts on "wayward girls" who, he believed, comprised a disproportionate number of second-generation Americans. The problem, as he saw it, was one of "imperfect Americanization" with the wayward child pulled between two sets of values-those of her parents and those of the broader culture. The patient's "mind and individuality try more or less unsuccessfully to survive the racial battle, which is duplicated and intensified in its own soul." 45 At other times, racial characteristics, in his thinking, appear to have been inborn. Van de Wall believed that the African American girls with

\footnotetext{
${ }^{40}$ Richard Crawford, "Edward MacDowell and Musical Nationalism," in America's Musical Life: A History (New York, 2005), 372-86.

${ }^{41}$ Alex Ross, The Rest Is Noise: Listening to the Twentieth Century (New York, 2013). On shifting understandings of "noise" in art, see Khan, Noise, Water, Meat. On the politics of the noise/music distinction, see Jacques Attali, Noise: The Political Economy of Music (Minneapolis, 1985).

${ }^{42}$ Susan Hegeman, Patterns for America: Modernism and the Concept of Culture (Princeton, NJ, 1999). See also Joan Shelley Rubin, The Making of Middle/Brow Culture (Chapel Hill, NC, 1992); and Janice A. Radway, A Feeling for Books: The Book-of-the-Month Club, Literary Taste, and Middle-Class Desire (Chapel Hill, NC, 1997).

${ }^{43}$ Van de Wall, Music in Correctional Institutions, 51.

${ }^{44}$ Van de Wall, The Utilization of Music, 35. On music, race, and ethnicity, see Ronald Radano, Lying Up a Nation: Race and Black Music (Chicago, 2003); Charles Hiroshi Garrett, Struggling to Define a Nation: American Music and the Twentieth Century (Berkeley, CA, 2008); Marybeth Hamilton, In Search of the Blues: Black Voices, White Visions (New York, 2009); and Miller, Segregating Sound.

${ }^{45}$ Van de Wall, "Music in Correctional Institutions," 54.
} 
whom he worked "don't need any instruction in emotional expression," because "they possess that quality by virtue of birth." He claimed that many of these patients knew nothing about black music when he first encountered them. Once instructed in "her own race's art," however, the patient excelled in its performance. "It is like striking a match," he wrote. "All is there, except the fire to light it. Racial experience, racial taste, racial efficiency, characteristic racial self-expression-it functions at once." 46

Van de Wall was less explicit about the gendered assumptions he made regarding his charges, but they occasionally surfaced in his published statements. In 1923, for example, he expressed the opinion that instrumental ensembles were an "ideal goal" in boys' institutions, but not, apparently, in those housing female patients and prisoners. Conversely, piano playing-though generally impractical in the institutional setting-represented a suitably feminine field of instrumental endeavor. ${ }^{47}$ In making these distinctions, Van de Wall drew on stereotypes-dating back at least to the Renaissance-regarding the kinds of musical performances off-limits to women and girls. In fact, in his 1528 guide to conduct, The Book of the Courtier, Baldesar Castiglione had expressed the gendered logic that would structure musical performance in Europe and the United States for a half millennium:

Even those [activities] that are becoming to a woman I would have her practice in a measured way and with that gentle delicacy that we have said befits her ... the musical instruments that she plays ought in my opinion to be appropriate to this intent. Consider what an ungainly thing it would be to see a woman playing drums, fifes, trumpets, or other like instruments; and this because their harshness hides and removes that suave gentleness which so adorns a woman in her every act. ${ }^{48}$

Instruments that required of the musician wild gestures or that produced an inordinate amount of sound violated emerging standards of femininity based on bodily reserve, passivity, and unobtrusiveness. Keyboard instruments such as the harpsichord and the piano, on the other hand, required little bodily movement and produced a moderate volume of sound. Importantly, these instruments were also too heavy to move, meaning they-and the individuals charged with playing them-would be sequestered to the feminine space of the domestic parlor. By 1936, Van de Wall's commitment to patriarchy had softened. In his Music in Institutions, he allowed that in small, mixed-sex institutions, male and female inmates might profitably cooperate in the production of orchestral music. Even here, however, Van de Wall may have had in mind a gendered division of musical labor. By the end of the nineteenth century, certain orchestral instruments (including the violin and cello) had become acceptable for women and girls, and he might have assumed that these instruments would be placed in the hands of female orchestra members. ${ }^{49}$

Regardless of the patient's race or gender, Van de Wall's music therapy sought, ultimately, to reconcile the individual to his or her role in the capitalistic social order. Here, Van de Wall's music therapeutic regimen resembled nothing so much as nineteenth-century "moral treatment." In Europe the first institutions for the seclusion of the mentally ill arose as early as the late Middle Ages but were relatively rare until the late seventeenth century when privately run "madhouses" proliferated. To distract inmates from their mad thoughts (and hopefully return them to a state of mental equilibrium), madhouse attendants subjected them to a wide range of terrors and miseries including beatings, poisonings, bleedings, near drownings,

\footnotetext{
${ }^{46}$ Ibid., $68-9$.

${ }^{47}$ Ibid., $47-72$.

${ }^{48}$ Quoted in Rita Steblin, "The Gender Stereotyping of Musical Instruments in the Western Tradition," Canadian University Music Review 16, no. 1 (1995): 128-44, here 128-9.

${ }^{49}$ Van de Wall and Liepmann, Music in Institutions, 296.
} 
and cold-water baths. Following the late eighteenth-century innovations of France's Phillipe Pinel and the Quaker-run York Retreat in England, however, a new treatment paradigm emerged. Introduced into the United States very soon after, the "moral treatment" sought to treat patients humanely, dispensing with undue physical restraints and tortures. But it also appealed to the patient as a moral agent, guiding behavior through social suasion with the aim of re-integrating the afflicted into the bourgeois moral order of rights and responsibilities. ${ }^{50}$

In the United States, moral treatment persisted unchallenged until after the Civil War when overcrowded asylums made impossible the close observation and guidance called for by the moral treatment. At the same time, asylum populations grew increasingly composed of patients with age-related dementia, syphilis-induced insanity, and other incurable conditions. A culture of pessimism took hold among psychiatrists as cures grew rare and as conditions inside asylums deteriorated, and by 1900, the field of psychiatry and the mental institution were both in severe disrepute. Institutional psychiatrists responded by turning to narrowly "medical" approaches to mental illness in an attempt to secure scientific legitimacy. When Willem Van de Wall entered his first mental asylums in 1921, he discovered a world where the prescriptions for mental illness were, in large measure, various physical treatments including hot and cold baths, needle showers, induced fevers, and drug therapies. ${ }^{51}$

Van de Wall's therapeutic program rejected such external chastisement of the body for the earlier moral treatment's emphasis on persuasion as well as its emphasis on returning patients to middle class propriety and to economically productive pursuits. For example, in the case of juvenile offenders, he argued that institutionalization must "replace tendencies and practices of dishonesty, lying and theft by honest methods of correct valuation and respecting of truth and property." 52 There were sharp differences, however, between the old moral treatment and the vision of therapy as embodied in Van de Wall's musical sessions. Moral treatment, with its emphasis on close patient monitoring, had failed to keep up with the demands of quickly growing psychiatric institutions. If something like moral therapy were to survive in the twentieth century, it would have to jettison such inefficiencies in favor of a new bureaucratic ethos.

In 1922, Van de Wall presented a paper entitled "Music as a Means of Mental Discipline" to the sixth annual meeting of the Occupational Therapy Association. In the version of the talk published later in the Archives of Occupational Therapy, he appended several diagrams depicting "Music Organization in State Hospital Service." "Music organization," as understood by Van de Wall, entailed tasks such as scheduling classes, rehearsals, and performances; maintaining department property; keeping suitable records of inmates' progress; and so on. But Van de Wall's diagrams combined these properly music-therapeutic concerns with a byzantine flowchart, tracing the bureaucracy of the New York State Hospital Commission from the offices in Albany down to the equipment closets and rehearsal spaces of Islip State Hospital. This preoccupation with the bureaucratic technology of music therapy, of course, was not incidental. For Van de Wall and his occupational therapist allies, the question of how to insinuate themselves and their work into existing structures of personnel and funding was just as important as that of running music classes. ${ }^{53}$

In keeping with the bureaucratic ethos of his work, the Dutch innovator also deployed political-economic justifications for music therapy. "If [the institution's] purpose is to convert as economically and speedily as possible unproductive citizens into productive ones," he argued, assuming the affirmative, "it must use every means available to bring about a turn to the good." Music was a crucial part of an economically rational rehabilitation program,

\footnotetext{
${ }^{50}$ Porter, Madness, 89-122; Whitaker, Mad in America, 3-18.

${ }^{51}$ Grob, "The Transformation of American Psychiatry," 538-41; Porter, Madness, 183-214. Shorter, A History of Psychiatry, 190-238.

${ }^{52}$ Van de Wall, Music's Mission, 214; Van de Wall, The Utilization of Music, 16.

${ }^{53}$ Van de Wall, "Mental Discipline," 13-6.
} 
not only because it worked, but also because it was cheap. In a 1923 article, Van de Wall encouraged readers to summon to mind "the many enormously expensive instruments and medicaments" employed in hospitals. These expensive devices and drugs, unfortunately, very often benefited only one patient at a time, absorbing an enormous amount of institutional resources. Music therapy, on the other hand, "can serve at one and the same time a hundred patients as well as one without the expenditure of additional funds, time or energy."

\section{Van de Wall, the Music Therapy Profession after 1936, and the ISO Principle}

In 1936 Willem Van de Wall published Music in Institutions, an undertaking in which, according to the work's title page, he had been "assisted by Clara Maria Liepmann." Though one might have never known from this lackluster billing, Liepmann herself was no "assistant," but a trained sociologist and well-published scholar in her own right who had studied penal reform in her home country of Germany. A fellowship with the Rockefeller Foundation had allowed her to continue this work in the United States where she met and soon collaborated with Van de Wall. The relationship between the two researchers eventually turned romantic, and a year after the publication of Music in Institutions, Van de Wall divorced his second wife and married Liepmann. ${ }^{55}$

In addition to serving as the catalyst for his third marriage, Music in Institutions represented the culmination of his work with the Russell Sage Foundation. After its publication, he left institutional music therapy to pursue different-though closely related-interests, including applications of music outside of prisons and hospitals. In some ways this change of emphasis was a natural progression. He had always insisted that prisoners' and mental patients' mental conditions were not discontinuous with "normality," but represented instead one end of a spectrum of well-adjustedness. Van de Wall's turn toward non-incarcerated populations, however, also received impetus from events in his own life. Beginning in 1925 he had served as a lecturer in social work and health and a visiting professor in adult education at Columbia University Teachers College. The experience brought him into regular contact with "normal" young adults for the first time in his career and reaffirmed him in the belief that non-institutionalized populations were in need of therapy. "In the colleges and universities," he wrote in 1929, "are found a rather surprising number of students whose emotional tendencies ... exert a destructive tendency over their physical and intellectual powers." If left untreated, he believed, "this functional lack of balance ... is liable to cause grave disturbances, breakdowns, and catastrophes sooner or later." ${ }^{\text {56 }}$

In 1936 Van de Wall signed on as a field representative for the American Association for Adult Education, conducting a six-month study of community music funded by the Carnegie Foundation. In New York, Kentucky, Ohio, Vermont, Delaware, and Wisconsin, Van de Wall discovered communities struggling with various degrees of success to create and maintain musical culture in the midst of modernity's upheavals. In every case, he believed, the situation could be improved with more robust musical leadership, to be achieved through bureaucratic means. With financial backing from the Carnegie Foundation, Van de Wall relocated to Lexington, Kentucky, in 1937 to conduct a one-year pilot program to foster musical leadership in the Commonwealth's urban and rural communities. Additionally he assumed a

\footnotetext{
${ }^{54}$ Van de Wall, "Music as a Means of Discipline," 150-60; Willem Van de Wall, "Music in the General Hospital," The Modern Hospital 11, no. 6 (Dec. 1923): 564-68.

${ }^{55}$ Clara Maria Liepmann, Die Selbstverwaltung der Gefangenen (Mannheim, Germany, 1928); Shelby M. Harrison to Clara Maria Liepmann, May 16, 1946, RSFR; Clair and Heller, "Willem Van de Wall," 174.

${ }^{56}$ Van de Wall, Music's Mission, 219-20; “Treating of Insane by Music Is Begun," Baltimore Sun, June 5, 1923, 4; Krikun, "Community Music During the New Deal," 167; Van de Wall and Liepmann, Music in Institutions, 15-6; Willem Van de Wall, "Music for Sub-Normal Children of the Public Schools," The Etude, Jan. 1929, 28; "Tests Music as Cure for Mental Disorder,” New York Times, Nov. 25, 1928, N7.
} 
faculty post at the University of Kentucky where he taught courses on "music as a social factor" and investigated the potential of the University's radio station and musical library as factors in community music enrichment. The program, apparently successful, received funding for an additional two years. From 1940-1943 Van de Wall taught music education at Louisiana State University. ${ }^{57}$

After finishing his appointment at Louisiana State University, Van de Wall helped prepare the 1944 "Survey on the Use of Music in Hospitals" for the National Music Council and was named chair of its Committee on the Use of Music in Hospitals in September the following year. At the annual meeting of the Council three months later, however, Chairman Van de Wall was absent. He had left for the American Occupation Zone in Germany to assume the position of chief of Adult Education in the Office of Military Government where his psychological and pedagogical insights would be brought to bear on the problem of de-nazification. Van de Wall finished his work with the Military Government in Germany in 1949, but then accepted a position in the office of the United States Land Commission in Bremen, a job that kept him away from the United States for two more years. ${ }^{58}$

As Van de Wall moved on to the greener pastures of adult education and employment with the federal government, American music therapy entered a period of rapid professional maturation. Because he was absent during these formative years, his direct influence waned as the profession rallied behind founders of training programs, journals, and professional organizations, as well as those employing more properly "scientific" research methods. Consequently, in the years that followed, those who chronicled music therapy's intellectual past tended to cast Van de Wall as a forerunner to the field rather than one of its founders. While acknowledging his importance to the development of the field as a body of thought and practice, encomiums to the Dutch harpist seldom articulated any concrete intellectual debts owed to Van de Wall. His concerns, emphases, and style were not those of the postwar cohort of music therapists struggling mightily to make of their field a respectable healthcare profession.

Music therapy's march to professional respectability received major impetus from an influx of state largesse. Beginning with the New Deal Federal Music Project in 1936, musicians found employment in various community roles. In addition to the expected rounds of park concerts and parades, however, a great many of these federally employed musicians found their way into prisons, hospitals, orphanages, and other public institutions where public officials noted their salutary effect on inmates. Such engagements continued when the Works Progress Administration replaced the Federal Music Project in 1939. During the Second World War, interest in the rehabilitative potential of music exploded, and organizations such as the National Federation of Music Clubs and the Musicians Emergency Fund organized volunteers for the purposes of playing in military hospitals. Following the war, these organizations continued to send volunteers into Veterans Administration hospitals and state hospitals. By this time, the musicians' work in military hospitals had also attracted official attention. In July 1945, the War Department issued a publication titled "Music in Reconditioning in Army Service Forces Convalescent and General Hospitals," recommending the use of music as an adjunct to more traditional forms of therapy in army hospitals. ${ }^{59}$

With the winds of historical crisis at their backs, music therapists began organizing. In 1940 the Music Teachers National Association formed a committee on functional music and two years later split the committee into a subcommittee on Music in Psychotherapy and one on Music in Industry. The National Music Council set up its own Committee on the Use of

\footnotetext{
${ }^{57}$ Willem Van de Wall, The Music of the People (New York, 1938), here 72; Eunice Barnard, "In the Classroom and on the Campus," New York Times, July 18, 1937, D5; Krikun, “Community Music During the New Deal," 168-9.

${ }^{58}$ Ruth Boxberger, "A Historical Study of the National Association for Music Therapy" (Ph.D. diss., University of Kansas, 1963), 58-62; “Dr. W. Van de Wall, Musician, Is Dead," New York Times, Aug. 29, 1953, 17.

${ }^{59}$ Boxberger, "The National Association for Music Therapy," 38-67.
} 
Music in Hospitals in 1945. Beginning with Michigan State College's inauguration of a fouryear degree program in 1944, several colleges and universities rolled out curricula in music therapy and by the end of the decade at least six colleges and universities offered degrees in the field. At the 1950 meeting of the Music Teachers National Association, the committee on Music in Therapy took the first step toward organizing music therapists nationally when it formed a subcommittee to organize a national music therapy body. On June 2, 1950, twenty representatives from organizations ranging from the Hymn Society of America to the Occupational Therapy Department at Columbia University convened in the council room of the American Music Center in New York City. The committee adopted a constitution and bylaws, elected officers, and named as its official publication the Hospital Music Newsletter, published by the Hospital Music Committee of the National Music Council. The National Music Therapy Association was born. ${ }^{60}$

Through all of these developments, Willem Van de Wall was conspicuously absent. When the leaders of the field met in New York to form the National Music Therapy Association in 1950, he was neither there nor among those named as officers of the new organization. The following year he was named a member-at-large of the executive committee, though in 1952 his name was conspicuously absent from that roster as well. After returning to the United States in 1951, he occasionally participated in the National Association for Music Therapy's functions, but his focus had already shifted from music therapy to adult education. Between 1952 and his death the following year, he worked for the Ford Fund for Adult Education and as an adult education consultant to the American Council of Voluntary Agencies for Foreign Service. ${ }^{61}$

Because of his distance from the sites and currents of music therapy professionalization, Van de Wall quickly waned in influence within music therapy circles, and his name and work appear only in passing in the early publications of the National Association for Music Therapy. ${ }^{62}$ Music therapists of the 1950 s were also eager to lay claim to the mantle of medical science. While anecdotal and philosophical ruminations filled their publications for another decade, by the end of the 1950s a behavioralist dispensation quite at odds with Van de Wall's talk of "vital energies" and self-discipline had taken root in the field. Because of its experimental orientation, behavioralist music therapy tended to spurn Van de Wall's preferred methods of music-making-live and participatory music-because both complicated efforts at experimental control. Instead, American music therapists relied increasingly in these years on recorded music, dispensing to test subjects industrially identical doses of music while measuring their posture, verbalizations, or movements. ${ }^{63}$

Later developments, as well as those originating in other national contexts, similarly pushed music therapy away from the model preferred by Van de Wall. In the United Kingdom, the team of Paul Nordoff and Clive Robbins as well as Juliette Alvin developed approaches to therapy that relied on musical improvisation. In the United States in the early 1970s, Helen Bonny developed "Guided Imagery and Music," a music-therapeutic approach combining "receptive" (listening-based) engagement with recorded music, accompanied with therapist-led visualization exercises. Also in the 1970s, Mary Priestley and Florence Tyson pioneered

\footnotetext{
${ }^{60}$ Ibid., 68-99.

${ }^{61}$ Esther Goetz Gilliland, ed., Music Therapy: 1951 Book of Proceedings of the National Association for Music Therapy, vol. 1 (Chicago, 1952), iii-v; Esther Goetz Gilliland, ed., Music Therapy: Second Book of Proceedings of the National Association for Music Therapy, vol. 2 (Lawrence, KS, 1953), v-vii; Boxberger, "A Historical Study of the National Association for Music Therapy," 107; "Dr. W. Van de Wall, Musician, Is Dead," 17.

${ }^{62}$ A notable exception is a 1952 article published in the Proceedings by B. A. Cockrell who engages substantively with Van de Wall's Music in Hospitals, regarding the "psychological goals" of music therapy. B. A. Cockrell, "Music Therapy for Tuberculous Patients," in Music Therapy: Second Book of Proceedings of the National Association for Music Therapy, ed. Esther Goetz Gilliland, vol. 2 (Lawrence, KS, 1953), 97-108.

${ }^{63}$ Leslie Bunt, Music Therapy: An Art Beyond Words (New York, 1994), 12.
} 
psychoanalytically informed approaches to music therapy, which exercised enormous influence on both sides of the Atlantic. While more humanistic in their orientation than the American behaviorists of the 1960s and 1970s, these innovators also advanced approaches to music therapeutics that apparently owed little to Van de Wall. Individualized therapy mainly replaced Van de Wall's explicitly collectivist emphasis on group singing, while improvisation replaced reliance on written compositions. Public performances by patients, always a mainstay of Van de Wall's work in mental hospitals, were sidelined as some came to believe that the practice was exploitative and that it was, at any rate, of dubious therapeutic value. ${ }^{64}$

Despite these shifts in culture, postwar music therapists continued to employ concepts and techniques Van de Wall had mobilized to great effect in prisons and asylums. One such concrete technique, dubbed the "ISO Principle" by later music therapists, originated as an emergency measure in Van de Wall's institutional work and later became entrenched within clinical music therapy. As the technique proliferated across the quickly professionalizing field of music therapy, however, it sloughed off much of Van de Wall's theoretical and rhetorical clothing. Where Van de Wall had spoken quite explicitly about its efficacy in controlling patients and prisoners, latter-day practitioners framed the ISO Principle as an agent of selfrealization or two-way communication between patient and therapist.

Van de Wall had indeed conceived of music therapy as a tool for "adjustment" to one's institutional environment, and to that end he employed a wide range of musical practices in his work, from technical instruction to instrumental performance. For his most intransigent, rowdy, or distracted charges, however, Van de Wall relied most heavily on group singing and it was in these raucous singing sessions that he perfected a potent weapon in the battle for musical crowd control. Van de Wall explained the logic of these singing sessions in 1923:

A half-hour of continuous singing, starting with a yelling of "The Star-Spangled Banner," gradually moderating in time and intensity to, finally, a softly hummed "Sleep, My Child, and Peace Attend Thee," never failed to exhaust surplus emotional energy, grasp the upward-groping soul, and mould the ill-mannered, self-advertising, noisy and obnoxious individual into a well-behaving, self-restrained and pleasingly cooperative personality. ${ }^{65}$

In institutions where patients were likely to be depressed or lethargic, Van de Wall might begin the exercise with more sedate material before finishing on an upbeat and optimistic number. In either case the strategy remained the same: Begin with songs matching the inmate's current, unsatisfactory mental state in order to create a connection. Then, gradually modulate subsequent selections toward the desired mood. ${ }^{66}$

If executed with skill, such strategic musical programming could achieve near-miraculous transformations of inmates' moods and behavior. Such was the outcome in 1921 or 1922, when Van de Wall entered the Women's Work House on Blackwell Island, New York City, and found the place unsettled. The guards had earlier that day confiscated some article of contraband, precipitating an enormous disturbance among the inmates. The row had been

\footnotetext{
${ }^{64}$ Juliette Alvin, Music Therapy (London, 1975). Bonny's early work in this direction is outlined in Helen L. Bonny and Louis M. Savary, Music and Your Mind: Listening with a New Consciousness (New York, 1973). For an account of the development of Guided Imagery and Music, see Helen L. Bonny, Music Consciousness: The Evolution of Guided Imagery and Music, ed. Lisa Summer (New Braunfels, TX, 2002), 43-68. See also Kenneth S. Aigen, The Study of Music Therapy: Current Issues and Concepts (New York, 2013), 40, 147; Mary Priestley, Music Therapy in Action (Saint Louis, MO, 1985); Florence Tyson, Psychiatric Music Therapy: Origins and Development (New York, 1981); and Youngshin Kim, "The Early Beginnings of Nordoff-Robbins Music Therapy," Journal of Music Therapy 41, no. 4 (Winter 2004): 321-39. For an overview of improvisational music therapy techniques, see Kenneth E. Bruscia, Improvisational Models of Music Therapy (Springfield, IL, 1987).

${ }^{65}$ Van de Wall, "Music in Correctional Institutions," 49.

${ }^{66}$ Van de Wall, The Utilization of Music, 35.
} 
contained just prior to Van de Wall's arrival, and he was advised not to bring the women together for a musical session. He would have none of it. He bid the cell doors opened, and the agitated inmates poured into his classroom. Van de Wall jumped onto the piano, which he "ordered a colored prisoner to play," and launched into a boisterous and loud rendition of the "Star Spangled Banner":

The mob gripped the suggestion and falling, in blind passion, in with any type of violent action, shouted and raved with me, taking over my tempo. The first number was followed by a gradual succession of calmer songs, intoned without an intermission of a second. The explosive rhythmical selections were systematically replaced by far more melodic and sedative tunes.... We wound up finally with such a song as "Hush-a-Bye, My Baby (The Missouri Waltz).... The mood from the furious had changed into one of pleased contentment. When the command came for them to go back to their cells they obeyed in orderly fashion without murmuring. ${ }^{67}$

Throughout his career Van de Wall would retell this story several times, and despite variations in detail and tone, it consistently and powerfully conveyed a vision of music therapy as he understood it-as a mechanism of social control. ${ }^{68}$

Van de Wall never named this mechanism, nor discussed how he arrived at it. Additionally, as his work targeted long-term program building in hospitals and prisons, he focused less and less on such "emergency" measures. His 1936 Music in Institutions barely mentioned it. All the same, the idea, shorn of its connections to Van de Wall, profoundly influenced the practice of music therapy in the twentieth and twenty-first centuries, and it did so largely through the influence of another practitioner-Ira M. Altschuler. Altschuler was born in the Ukraine in 1883 but as a child moved to Sweden with his family to avoid anti-Jewish violence. After graduating from Berne Medical School and practicing medicine for two years, he moved to the United States. There he studied neurology and psychiatry at Harvard before moving on to the University of Michigan for more training. In 1932 he accepted a position at Eloise State Hospital in Detroit as director of group therapy, enthusiastically introducing music into his department's curriculum five years later. It was from this institutional perch that Ira Altschuler theorized, experimented with, and implemented a range of new music-therapeutic concepts. $^{69}$

Altschuler outlined the "ISO Principle" (after the Greek isos, or "equal") in a 1941 article "The Part of Music in Resocialization of Mental Patients." According to this principle, it was first necessary that the music therapist match the music to the mental state of the subject before attempting to manipulate his or her behavior. "If a patient ... shouts, paces the floor, talks fast, and is elated," Altschuler suggested as an example, "we must adjust the volume of the music to the intensity of his shouting, the tempo of the music to his mental tempo, and the mood of the music to the patient's mood." These several dynamics he dubbed respectively, the "isovolumic," "iso-tempic," and "iso-moodic" principles. After having made contact with the patient in this way, the therapist would then be able to "arouse attention, modify the mood, [and] influence the mental tempo of the patient" by strategically modulating song selections toward the desired musical mood. ${ }^{70}$

\footnotetext{
67"How Music Is Saving Thousands," 614.

${ }^{68}$ Van de Wall, "Music as a Means of Discipline," 152-3.

${ }^{69}$ William B. Davis, "Ira Maximilian Altshuler: Psychiatrist and Pioneer Music Therapist," Journal of Music Therapy 40, no. 3 (Fall 2003): 247-63.

${ }^{70}$ Ira M. Altschuler, "The Part of Music in Resocialization of Mental Patients," Occupational Therapy \& Rehabilitation 20, no. 2 (Apr. 1941): 81-2. On the ISO Principle, see Penelope Gouk, "Objective Science or Just a Metaphor?," Nordic Journal of Music Therapy 10, no. 1 (Jan. 1, 2001): 65-8.
} 
The ISO Principle, of course, had been articulated in almost identical terms by Van de Wall two decades prior, and it had been a central component of his project of institutional inmate "adjustment." Altschuler may or may not have been aware of Van de Wall's earlier work in this vein, but the concept, so pregnant with opportunities for social control, decisively passed into the general fund of music-therapeutic wisdom and influenced the thinking of many, if not most, of the field's serious theorists. In their 1973 classic Music and Your Mind, Helen Bonny and Louis Savary called the ISO Principle "one of the most important rules to follow in listening to music in altered consciousness," and two years later Juliette Alvin wrote that "an experienced therapist ... tries to catch the mood of the group at the beginning and plays music reflecting that mood. Thus, he can reach the listeners at once and, if desirable, works from the one mood toward other feelings." In 1994 Leslie Bunt wrote that the ISO Principle "can still be regarded as the heart of much current music therapy practice," while influential Argentine music therapist Ronaldo Benenzon has elaborated it into "an infinite set of sound, acoustic, and movement energies that belong to an individual and give him a peculiar feature." His model includes "Gestalt ISO," "Universal ISO," "Cultural ISO," "Interactive ISO," "Familiar ISO," "Group ISO," "Environmental ISO," "Community ISO," and "Transcultural ISO."71

Despite these continuities, later practitioners came to understand the project of music therapy in terms quite different from Willem Van de Wall's. The latter had been explicit about music therapy's status as a tool of discipline. "Music," he wrote in 1924, "is indeed the most efficient general disciplinarian and moral agent in prison management." "One song of thirty-two bars of music ..." he told the New York Times, "accomplishes more toward esprit de corps in an institution than all the efforts of keepers, matrons, and disciplinarians." Such songs as "Old Black Joe," "Perfect Day," and "The Missouri Waltz," he added, "are great favorites among the defective and delinquent and have proved themselves a disciplinary force of the highest kind." ${ }^{72}$ By the end of the twentieth century, however, music therapists had de-emphasized the coercive element of their craft. In 1994, therapist Leslie Bunt described his work with a three-and-a-half-year-old patient named John: "In the individual session I searched for a way to be in 'iso relation' with John," he wrote, "exploring various moods, speeds, and rhythms to match his playing and find a point of contact. Once we reached this point, then we began to interact musically.” In Bunt's understanding, the ISO Principle was an agent of communication and mutuality-not control. ${ }^{73}$

\section{Conclusion}

Whether they knew it or not, music therapists who took up the ISO Principle and similar techniques in the postwar period adapted technologies of institutional control for use on the wider population. On at least one occasion, a practitioner even pushed the ISO Principle out of the clinical setting altogether. In the 1960s, Dr. Leo Shatin, professor of psychiatry at the New Jersey College of Medicine and Dentistry, worked with New York's Westminster Recording Company to release a three-volume series of long-playing records titled "Affect Your Emotions Through Music." Prospective purchasers of these recordings were informed via copy on the album sleeves that "recent scientific studies" had demonstrated the efficacy of sound and music in affecting human emotions. "Now," the copy continued, "for the first time, the combined efforts of science and art have developed a recording of programmed music which can serve the important function of helping the individual alter his mood."

\footnotetext{
${ }^{71}$ Davis, "Ira Maximilian Altshuler"; Bonny and Savary, Music and Your Mind, 29; Alvin, Music Therapy, 123; Bunt, Music Therapy, 33; Ronaldo Benenzon, “The Benenzon Model,” Nordic Journal of Music Therapy 16, no. 2 (2007): 148-59.

${ }^{72}$ Van de Wall, The Utilization of Music, 17; "Curative Powers," 12.

${ }^{73}$ Bunt, Music Therapy, 33.
} 
In fact, this was not the first time behavioral scientists and the recording industry had joined forces to help Americans manage their emotions in the safety and comfort of their own homes. Beginning in 1919, for example, Thomas A. Edison, Incorporated, had collaborated with the psychologist Walter Van Dyke Bingham to produce a publication entitled Mood Music: A Compilation of 112 Edison Re-Creations According to 'What They Will Do for You.' The booklet, based on large numbers of listener surveys, categorized Edison Company phonograph recordings according to their putative emotional effects. The right Edison recording (or "Re-Creation") could "Stimulate and Enrich Your Imagination," "Bring You Peace of Mind," or encourage "Moods of Wistfulness." "74

What was novel about the records produced by Dr. Shatin and Westminster, however, was their encapsulation of decades of experimental and clinical insights into the effect of music on human mood and behavior. Specifically, the "Affect Your Emotions Through Music" series relied on the ISO Principle, reconfigured in Shatin's work into the "ISO/VECT Principle."75 Side A of the second record of the series offered four selections of classical music identified only on the basis of their emotional effects: "From Restless to Tranquil," "Agitated to Serene," "Troubled to Soothing," and "Tense to Restful." The purchaser was expected to select the track most closely matching his or her current-unsatisfactory-mood, set the needle in the appropriate groove of the record, and listen. In a few minutes, the listener's emotional state would be "adjusted." The final track, "Tense to Restful," was apparently intended to induce sleepiness, and having achieved a "restful" state, the listener flipped to Side B, given over in its entirety to a single track- "Maintain Restful Mood"-and went to sleep. The project of adjusting one's mood could go on even past the hours of daytime consciousness. ${ }^{76}$

Music therapy and the ISO/VECT recordings represented one stream in a rapidly broadening torrent of "self-help" media-a transformation dovetailing with an increased visibility of mental health professionals and psychological concepts in postwar American life. In this period, psychiatrists and psychologists proved increasingly willing to diagnose quotidian human complaints as mental illness, while average Americans came to understand themselves and their relationships with others in psychological terms learned from novels, movies, and television. ${ }^{77}$

Variously referred to as the therapeutic ethos, the culture of therapy, therapeutic culture, or the culture of narcissism, these transformations in American life have long drawn comment from scholars. Historians and cultural critics have traced the origins of therapeutic culture to a wide variety of historical moments and currents. They find its early stirrings in the nineteenth-century mind cure movement or in a late nineteenth-century feeling of "weightlessness," brought on by urbanization, technological development, market relations, and secularization. $^{78}$ Therapeutic culture has been treated as an outgrowth of the rise of psychoanalysis in America and as a response to post-World War II intellectual malaise. ${ }^{79}$

\footnotetext{
${ }^{74}$ Hui, “Lost," 139-42.

${ }^{75}$ The term "ISO" technically only captured the technique's emphasis on matching the patient's mood. Shatin pointed out that the goal was to guide the patient into new moods in stepwise fashion-what he called "vectoring"; hence, "ISO/VECT." Leo Shatin, "Alteration of Mood via Music: A Study of the Vectoring Effect," The Journal of Psychology 75, no. 1 (May 1970): 81-6.

${ }^{76}$ Leo Shatin, Affect Your Emotions Through Music (New York, Westminster Records, n.d.), LP.

${ }^{77}$ On therapy and postwar media, see Luke Stark, “Albert Ellis, Rational Therapy and the Media of 'Modern' Emotional Management," History of the Human Sciences 30, no. 4 (Sep. 2017): 54-74. On the therapeutic in postwar popular culture, see Eva S. Moskowitz, In Therapy We Trust: America's Obsession with Self-Fulfillment (Baltimore, 2008). As Ellen Herman has shown, the postwar years also found American psychologists implicated in far-reaching projects of state and corporate social control. Ellen Herman, The Romance of American Psychology: Political Culture in the Age of Experts (Berkeley, CA, 1997).

${ }^{78}$ Moskowitz, In Therapy We Trust, 10-27; T. J. Jackson Lears, "From Salvation to Self-Realization: Advertising and the Therapeutic Roots of the Consumer Culture, 1880-1930," Advertising \& Society Review 1, no. 1 (Jan. 2000).

${ }^{79}$ Eva Illouz, Saving the Modern Soul (Berkeley, CA, 2008), 22-57. See also Philip Rieff, The Triumph of the Therapeutic: Uses of Faith after Freud, 40th Anniversary edition, 2nd printing (Wilmington, DE, 2007). Philip
} 
These interpretations overlook an important wrinkle in the history of American therapeutic culture-its partial origins in prisons and psychiatric hospitals. In most accounts, therapeutic culture originates in the earnest soul-searching of an anxious middle class. Only then is it turned on those at the margins by an American bourgeoisie bent on increasing productivity and consumption. As Van de Wall's career highlights, however, at least some therapeutic practices emerged directly from efforts to control racial, class, gender, and cognitive minorities before undergoing a process of sanitation that made them acceptable for use on the late twentieth-century middle class.

The ISO Principle's rapid transformation from agent of institutional management to a massdistributed method of "self-help" owes much to music's status as art or recreation-a status imparting an air of innocuousness denied to more "serious" forms of psychiatric intervention. Music therapy and the ISO Principle are not likely to be isolated cases in this regard. For the past two centuries, artists and clinicians have introduced interned and non-interned populations to various forms of arts therapy. Beginning in the early nineteenth century, physicians had touted the value of painting, dancing, drama, and poetry in restoring patients to the cycles of "normal" bourgeois activity. By the end of the century, new understandings of the arts as a peculiarly subjective sphere of human endeavor pushed mental health professionals and artists to theorize a special relationship between them and mental health. Following the lead of Cesare Lombroso and Max Nordau, for example, psychiatrists turned to their patients' drawings and paintings as aids in diagnosis. ${ }^{80}$ In the years before World War I, Isadora Duncan, Ruth St. Denis, and Ted Shawn drew on ancient and non-Western examples to forge a "modern dance" that purported to restore dance's role as a salutary mediator between mind and body. ${ }^{81}$

It was in the interwar period, however, that transnational interest in the practical application of the arts to therapy exploded. While the intrepid Willem Van de Wall was venturing into prisons and psychiatric institutions in the 1920s, the Romanian-American psychiatrist Jacob Levy Moreno began his own work in psychodrama in New York City. ${ }^{82}$ Across the Atlantic,

Cushman has provocatively characterized psychoanalysis as a "technology of the self" that facilitated the construction of a new consumerism-friendly subjectivity freed from prior social and spiritual entanglements. Philip Cushman, Constructing the Self, Constructing America: A Cultural History of Psychotherapy (Boston, 2005); Christopher Lasch, The Culture of Narcissism: American Life in an Age of Diminishing Expectations (New York, 1978), xiii-xviii.

${ }^{80}$ On the history of art therapy, see Patricia St. John, "A Short History of Art Therapy Practice in the United States," in Creative Arts Therapies Manual: A Guide to the History, Theoretical Approaches, Assessment, and Work with Special Populations of Art, Play, Dance, Music, Drama, and Poetry Therapies, ed. Stephanie L. Brooke (Springfield, IL, 2006), 3-20; Maxine Borowsky Junge, The Modern History of Art Therapy in the United States (Springfield, IL, 2010); Megan Robb, “The History of Art Therapy at the National Institutes of Health," Art Therapy: Journal of the American Art Therapy Association 29, no. 1 (2012): 33-7; and Rachel Cohen, Outsider Art and Art Therapy: Shared Histories, Current Issues and Future Identities (London, 2017).

${ }^{81}$ On dance and dance therapy, see Christina Devereaux, Susan Kleinman, Grace Marie Mangino Johnson, and Kelsey Witzling, “American Dance Therapy Association Historical Timeline: 1966-2016," American Journal of Dance Therapy 38, no. 2 (Dec. 2016): 437-54; Christine Caldwell and Lucy Leighton, "Dance/Movement Therapy, Women's Rights, and Feminism: The First 50 Years," American Journal of Dance Therapy 38, no. 2 (Dec. 2016): 279-84; Talia Saraceno, "Dance Therapy: In This Moment, We Live" (MA thesis, State University of New York at Binghamton, 2015); Judith Richardson Bunney, "Honoring History and Heritage: Roots for New Heights: Marian Chace Memorial Foundation Annual Lecture," American Journal of Dance Therapy 35, no. 1 (June 2013): 5-17; Laurice D. Nemetz, "Moving with Meaning: The Historical Progression of Dance/ Movement Therapy," in Creative Arts Therapies Manual: A Guide to the History, Theoretical Approaches, Assessment, and Work with Special Populations of Art, Play, Dance, Music, Drama, and Poetry Therapies, ed. Stephanie L. Brooke (Springfield, IL, 2006), 95-108; Claire Schmais and Elissa Queyquep White, “ADTA: Where, When and How It All Began," American Journal of Dance Therapy 18, no. 1 (Mar. 1996): 5-20; and Hillel Schwartz, "Torque: The New Kinaesthetic of the Twentieth Century," in Incorporations, eds. Jonathan Crary and Sanford Kwinter (New York, 1992), 71-127.

${ }^{82}$ Andrew M Gaines and Jason D Butler, "The History, Trends and Future of North American Drama Therapy," in Routledge International Handbook of Dramatherapy, eds. Sue Jennings and Clive Holmwood (New York, 2016), 
psychiatrists Walter Morgenthaler of Switzerland and Hans Prinzhorn of Germany published influential monographs that touted painting's salutary effects on patients' mental health. And at the very end of the interwar period, the dancer and instructor Marion Chace inaugurated a dance therapy program at Washington, DC's St. Elizabeths Hospital-the first of its kind in the United States.

Those exploring the therapeutic efficacy of art, dance, drama, and poetry were slower to professionalize than were their counterparts in music. Still, in the years following World War II they established their fields as proper professions, setting up academic journals, conferences, and professional organizations. They founded the American Dance Therapy Association in 1966; the American Art Therapy Association as well as the American Association of Poetry Therapy in 1969; and the North American Drama Therapy Association in 1979. If the story of Willem Van de Wall and his music therapy are any indication, the history of these practices and professions is a promising site on which to explore the tangled linkages connecting art and therapy on one hand and twentieth century social control on the other. ${ }^{83}$

Of course, Van de Wall's was a particular logic of social control, and it would be hyperbolic and irresponsible to conflate the discipline of music therapy with that of hydrotherapy, physical restraints, or electro-shock therapy. Indeed, the "soft" coercion exercised by Van de Wall was almost certainly considered by many of his charges a welcome reprieve from the "hard" variety usually apportioned to them in spades. Music therapy has done a great deal of good for a great many people. Music therapists and other mental health workers, often motivated by nothing so much as their vision of a healthier, happier, more well-adjusted tomorrow, have given of themselves generously. But visions of the good life have played just as important a role as the pursuit of social control in the evolution of twenty-first-century misery. The two may not be linked by accident so much as by necessity.

J. Martin Vest is a research associate in the University of Michigan Department of History. He is at work on his first book, tentatively titled Vox Machinae: Phonographs and the Birth of Sonic Modernity, 1877-1930.

52-63; Phil Jones, Drama as Therapy: Theory, Practice and Research (New York, 2019); Phil Jones, "An Analysis of the First Articulation of Drama Therapy: Austin's 'Principles of Drama-Therapy: A Handbook for Dramatists' (1917)," The Arts in Psychotherapy 40, no. 3 (July 2013): 352-57; Sally Bailey, "Ancient and Modern Roots of Drama Therapy," in Creative Arts Therapies Manual: A Guide to the History, Theoretical Approaches, Assessment, and Work with Special Populations of Art, Play, Dance, Music, Drama, and Poetry Therapies, ed. Stephanie L. Brooke (Springfield, IL, 2006), 214-22; John W. Casson, "Living Newspaper: Theatre and Therapy," The Drama Review 44, no. 2 (May 2000): 107-22; Brenda Meldrum, "Historical Background and Overview of Dramatherapy," in The Handbook of Dramatherapy, eds. Sue Jennings, Ann Cattanach, and Steve Mitchell (London, 1994), 12-27; and Martin Hugh Davies, "The Origins and Practice of Psychodrama," The British Journal of Psychiatry 129, no. 3 (Sep. 1976): 201-6.

${ }^{83}$ On the history of poetry therapy, see Mari Alschuler, "Poetry, the Healing Pen," in Creative Arts Therapies Manual: A Guide to the History, Theoretical Approaches, Assessment, and Work with Special Populations of Art, Play, Dance, Music, Drama, and Poetry Therapies, ed. Stephanie L. Brooke (Springfield, IL, 2006), 56-64. 